\title{
Separation of powers: new perspectives and empirical findings-introduction
}

\author{
Eli Salzberger $\cdot$ Stefan Voigt
}

Published online: 23 January 2009

(C) Springer Science + Business Media, LLC 2009

\section{I}

The doctrine of separation of powers is an important pillar of modern liberal democratic theories of the state. While we find discussion of the separation of powers as a crucial factor in the organization of government in Plato's writings, the modern doctrine of separation of powers originates from the writings of John Locke, who advocated the separation between the legislature and the executive; Montesquieu, who introduced the judiciary as the third branch of government; and the American founding fathers, particularly Madison and Hamilton, who contributed to the desirable mode of relations between the powers-checks and balances, and introduced the horizontal separation of powers between central and local governments. Over the last decades, the structure of governance and the factually implemented separation of powers have experienced far-reaching changes. In some areas of the world, entirely new levels of governance have emerged (such as the supra-national level of the European Union). In addition, voluntary submission to internationally agreed institutions and 'rules of the game' (e.g., the WTO) plays an increasingly important role in all parts of the world. Domestically, the trend towards transparency and accountability has led to the creation of a number of new actors such as central banks, independent competition agencies, election commissions, anti-corruption commissions and alike. In many states, the possibility for direct participation in political decision-making by citizens, which bear on the original rationales of the doctrine of separation of powers, has markedly increased over recent years.

\footnotetext{
E. Salzberger

University of Haifa, Mount Carmel, 31905 Haifa, Israel
}

S. Voigt (ه)

University of Marburg, Marburg, Germany

e-mail: voigt@wiwi.uni-marburg.de 
While many changes have taken place with regard to the de facto separation of powers, theorizing about these changes has been lagging behind. This seems to be true on both the normative and the positive levels of analysis. It also seems to be true regarding both the causes and the effects of this "new" separation of powers. These developments were the motivation for a workshop on the topic that took place at the University of Haifa in December 2007. This symposium contains selected papers presented at Haifa and aims both to present discussion of some of the new features of the modern separation of powers and to address the possible interdependencies among these features.

\section{II}

Liberal political theory is the most important normative foundation of the doctrine of separation of powers. Liberal thinking rejects natural law or deontological morality as the foundations for collective organization and action. It assumes that there is no value in society or in the state save its individuals' values and that all individuals' values or preferences ought to be recognized equally. Thus, collective action and institutional design are intended to maximize individual preferences. In a utopian world of no decision-making costs the best way to materialize these foundations is through consensual collective action in which all citizens participate. Such a principle would guarantee that all decisions are Pareto optimal and utility enhancing. However, the costs of collective action do not allow this system of government. The Liberal democratic paradigm of the last two centuries, therefore, is founded on the idea of a social contract-constitution-which is meant to reflect consensual principles, including the delegation of day to day governance to representatives elected and operating on the bases of majority decision-making. The substantive parts of the constitution-bill of rights_and its structural part-dividing the powers of government and the relations between them-aim to guarantee that public decision-making does not transgress the original consensus. Governments are means to enhance individuals' preferences and justification is required for any limits on personal freedoms. The separation of powers is a structural element, which is a necessary (but not sufficient) condition to protect individual liberty when citizens (principals) have delegated powers to political decision makers (agents) in order to benefit from specialization (division of labor).

The principle of separation of powers is composed of several elements: separation of functions (between the constitutional stage and the post-constitutional stage and within the post-constitutional stage between rule making, rule execution and rule adjudication), separation of agencies (constitutional court enforcing the constitution, and legislature, executive and judiciary operating in the post-constitutional stage), separation of persons and, most importantly, the structure of relations between the powers (pure separation, checks and balances on the decision level as in most presidential systems - or on the personal level as in most parliamentary systems).

The papers presented here consider aspects of the detailed specifications of this general normative scheme. They include: the choice between parliamentary and presidential or mixed systems, the introduction of referenda as a component of 
governance, the protection of principals' interests through the delegation of decisionmaking powers to international bodies, the choice between different ratification procedures as an instrument in the hands of governments, the roles and independence of the judiciary as a function of the other components of separation of powers, the delegation of powers to other independent agencies such as central banks and competition authority on the desirable structure of government and the resort to direct democracy.

Positive analysis of separation of powers does not conform necessarily with normative analysis. In reality, constitutions are not the result of popular consensus and they differ as a result of different real-world constitutional processes. Similarly, actual structures of government are also the result of post-constitutional decision-making. For example, the construction of independent agencies, which are not specified in the constitution, might be the result of rational decisions by politicians to delegate powers in order to maximize their preferences. Likewise, the construction of international and supra-national institutions can be analyzed in the framework of delegation theory, not only in the narrow economic model of politicians assumed to maximize their powers and chances of re-election, but also in the broader rational choice context assuming politicians who are trying to fulfill their ideologies or preferences concerning the good of society, constrained by the election cycle and the constitutional structure. It is interesting to examine the ramification of the different basic systems of government on the post-constitutional dynamics of delegation or separation of powers.

All these theoretical conjectures provide fascinating grounds for empirical examination, which can focus on examining the validity of the theoretical hypotheses, as well as the broader implications of different modes of separation of powers on macro indicators, both economic and others. The present collection of papers combines theoretical perspectives and empirical findings.

\section{III}

Discussions on the economic effects of constitutions, at least among economists, have been dominated by the dichotomy between presidentialism and parliamentarianism. The rising relevance of mixed systems, i.e., systems with a popularly elected president and a government that depends on the confidence of the legislature, has been largely neglected. José Antonio Cheibub and Svitlana Chernykh take up this issue and ask about the democratic performance of mixed systems.

For a long period the statement that an independent judiciary has a number of positive effects vis-à-vis the normative political theory of the state, but also in terms of economic performance, was largely uncontested-but also untested. After a number of attempts to measure the actual independence of the judiciary, we can now be fairly certain that an independent judiciary does, indeed, have significant positive effects. This leads immediately to the next question, namely what the determinants of judicial independence are. Fabio Padovano analyzes the degree to which the independence of two supreme Italian courts (the constitutional and the administrative) is determined by the behavior of the other government branches that change over time. These findings relate to an important theoretical debate about the positive analysis of judicial independence, and more specifically, about weather politicians 
would be interested to curtail judicial independence and the importance of constitutional constrains on them.

The economic effects of direct democracy have been a subject of literature mainly focusing on the US and Switzerland. Only recently have cross-country studies begun to appear. Often, the effects of direct democratic institutions have been analyzed as if they have impact upon the dependent variables "in splendid isolation". Simon Hug takes up this observation and pleads for a more systematic taking into account of possible interaction effects of direct democratic institutions with other institutions.

Central banks that can pursue a stable monetary policy, independent from government tutelage, are usually interpreted as a necessary condition for low inflation. The idea of other agencies independent from direct government seems to spread very fast; it has been applied to the implementation of competition law, to the regulation of telecommunications as well as to energy supply, other public utilities and the financial markets. The evidence seems to show that independent regulators are more successful in these policy areas too. But what do independent agencies mean with regard to the separation of powers? Is there an optimum number of independent agencies beyond which negative effects outweigh their advantages-perhaps because the legitimacy of state action decreases? These are some of the question taken up in the paper by Marc Quintyn.

The debate on the economic effects of constitutions has shown that election systems - proportional or majority rule — can have important consequences. To date, the effects of commissions that are to monitor the lawful execution of elections have not been analyzed systematically. Anne van Aaken discusses both the role of domestic election commissions as well as those of international election monitors.

These contributions have primarily dealt with domestic institutions. Yet, globalization also implies that the separation of powers extends beyond the nation-state. Tom Ginsburg asks whether the propensity to delegate powers in the first instance is at least partially determined by the domestic institutional structure of a country, and finds some evidence in favor of this hypothesis.

The paper by Thomas König and Daniel Finke can be interpreted as an analysis of the strategies chosen by politicians to create and modify international delegation vis-à-vis the rules regulating the ratification of international treaties. The authors look at how EU primary law (i.e., supranational law) is ratified into domestic law. At times, politicians have a choice of procedures, the most important of which is whether they put the proposal to a referendum.

Delegating powers beyond the nation-state is connected with numerous problems of both accountability and legitimacy. Eyal Benvenisti and George Downs describe these problems and discuss whether domestic courts might be adequate players to ensure both accountability and legitimacy.

\section{IV}

The papers presented here do not answer all the theoretical questions outlined above and do not fill all missing parts in this complicated puzzle. Yet, they contribute not 
merely to the pure theory, but also on the empirical level, beyond mere story telling. We believe that this symposium is very timely, and we hope that it will provide a basis for more refined research on the new separation of powers.

We thank the German-Israeli Foundation for the grant that made possible the research on separation of powers and the workshop in which the papers in this volume were presented, debated and improved. We also thank the Haifa Posen Forum for the Study of Jewish, European and Israeli Political Thought for supporting the project. 